\title{
Influence of the tillage method on the development of leaf diseases of winter wheat
}

\author{
O. Yu. Kremneva ${ }^{1, *}$, K. E. Gasiyan ${ }^{1}$, A. V. Ponomarev $^{1}$, A. Kokhmetova ${ }^{2}$, and S. I. \\ Novoseletsky ${ }^{3}$ \\ ${ }^{1}$ Federal Research Center of Biological Plant Protection, Krasnodar, 350039, Russia \\ ${ }^{2}$ Institute of Plant Biology and Biotechnology, Timiryazev Street, 45, Almaty, 050040, Kazakhstan \\ ${ }^{3}$ Kuban state agrarian University named after I. T. Trubilin, Krasnodar, 350004, Russia
}

\begin{abstract}
To carry out effective plant protection measures, it is necessary to take into account all the factors affecting the quality of the crop. The aim of our research was to study the degree of development of leaf diseases of winter wheat and the rate of infestation of crops, depending on the tillage method. The studies were carried out in 2019-2020 at the experimental plots of "Kuban educational farm" in Krasnodar. For the research, four experimental plots with Steppe variety of soft winter wheat were created, where various soil cultivation systems were applied: 1 - No-Till (zero technology), 2 - moldboard-free technology, 3 - recommended, 4 - moldboard technology. The article presents data on the degree of development of diseases and the degree of infestation of winter wheat plants in the crops of test plots with various tillage systems. It was found that the most preferable is the use of the recommended type of treatment, since with it the least number of diseases develops and the degree of development of pathogens is reduced by 2-3 times in comparison with other options. The influence of the tillage method on the number and composition of phytopathogen spores was revealed.
\end{abstract}

Wheat is one of the first plants introduced by man into culture, and at the moment it is the main crop that provides food for the world's population. While in 1971 the world wheat growing area was 210.3 million hectares, in 2019 the area occupied by wheat was 218 million hectares [1]. Increasing the density of crops requires special attention to protecting wheat against pests, for which it is necessary to carry out accurate phytosanitary monitoring on time and regularly, which will take into account all factors affecting the quality of wheat. One of these factors is the tillage method, since soil fertility and conditions for the development of culture depend on it. Correctly selected technology of mechanical soil cultivation can influence the number of pathogens, pests and weeds, as well as their harmfulness [2-4]. Among the diseases pathogens, the decrease in wheat yield is mainly caused by fungal phytopathogens (Puccinia triticina Erikss., Blumeria graminis (DC.) Speer f. sp. tritici Marchal, Pyrenophora tritici-repentis Died., Septoria tritici Rob. et Desm.,) [5-7]. For effective protection, it is important to understand the quantitative and qualitative composition of the spores of fungal pathogens (as an indicator of the presence of an aerogenic infection).

\footnotetext{
*Corresponding author: kremenoks@mail.ru
} 
The aim of the research is to study the influence of the tillage method on the development of leaf diseases of winter wheat and the contamination of crops with pathogens.

The experiment was carried out at the sites of Kuban educational farm in Krasnodar. The "Steppe" variety of soft winter wheat was chosen as the object of the study, which was submitted for the State variety testing in 2015. The variety is a variety of lutescens with a high potential yield (over 110 c / ha), with high flour-grinding and baking qualities. The "Step" variety is short-stemmed and resistant to lodging. Recommended for cultivation in the North Caucasus region. The variety has moderate resistance to brown rust, powdery mildew and septoria blight, resistant to yellow rust, moderately susceptible to fusarium head blight, susceptible to head smut [8].

For the research, four experimental sites were created, where various tillage systems were applied:

Option 1 (No-Till, zero technology) - direct seeding;

Option 2 (moldboardless technology) - disking by 10-12 cm, moldboardless processing by 18-22 cm (BDT-7, PCHN-3.5);

Option 3 (recommended technology) - disking by 10-12 cm, moldboard plowing by 18-22 cm (BDT-7, PLN-5-35);

Option 4 (moldboard technology with periodic deep loosening) - disking by 10-12 cm, moldboard plowing by 18-22 cm, (PLN-5-35, BDT-7).

To determine the degree of development of wheat leaf diseases, field surveys were carried out using international scales of plant infestation [9-10]. To determine the qualitative and quantitative composition of the spores of pathogens, in parallel with field counts, air samples were taken over crops using a portable determinant of plant infestation OZR-1mp [11].

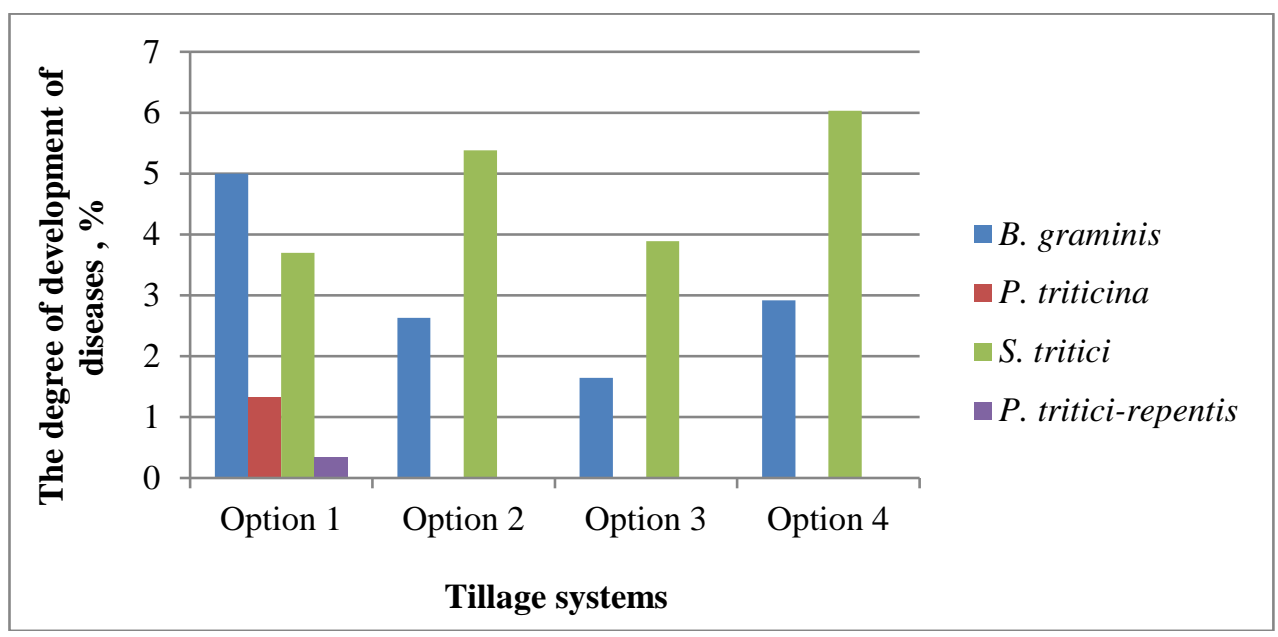

Fig. 1. Degree of development of wheat disease pathogens depending on the tillage system (average for three dates of registration).

Analysis of the data (Fig. 1), obtained by means of visual counting, shows that the maximum variety of leaf diseases (powdery mildew, brown rust, septoria blight and tan spot) was revealed in the plots with no tillage technology. At the same time, powdery mildew reached the highest degree of development - 5\%. On plots with moldboardless, recommended and moldboard tillage technologies, only powdery mildew and septoria blight were found among the diseases. It is clearly seen from the figure that the tillage type does not affect the development of septoria spot, since in all areas the development of the disease was from 3 to $6.1 \%$. The influence of the type of soil treatment on the development of leaf rust and yellow 
leaf spot is also clearly visible. These pathogens were recorded only in the experimental site No. 1 (No-Till).

Analysis of the data on infestation of crops showed that the largest number of powdery mildew spores was found in areas with moldboardless and recommended tillage type. The largest number of spores of rust and pyrenophorosis pathogens was observed in areas with no tillage (Fig. 2-4).

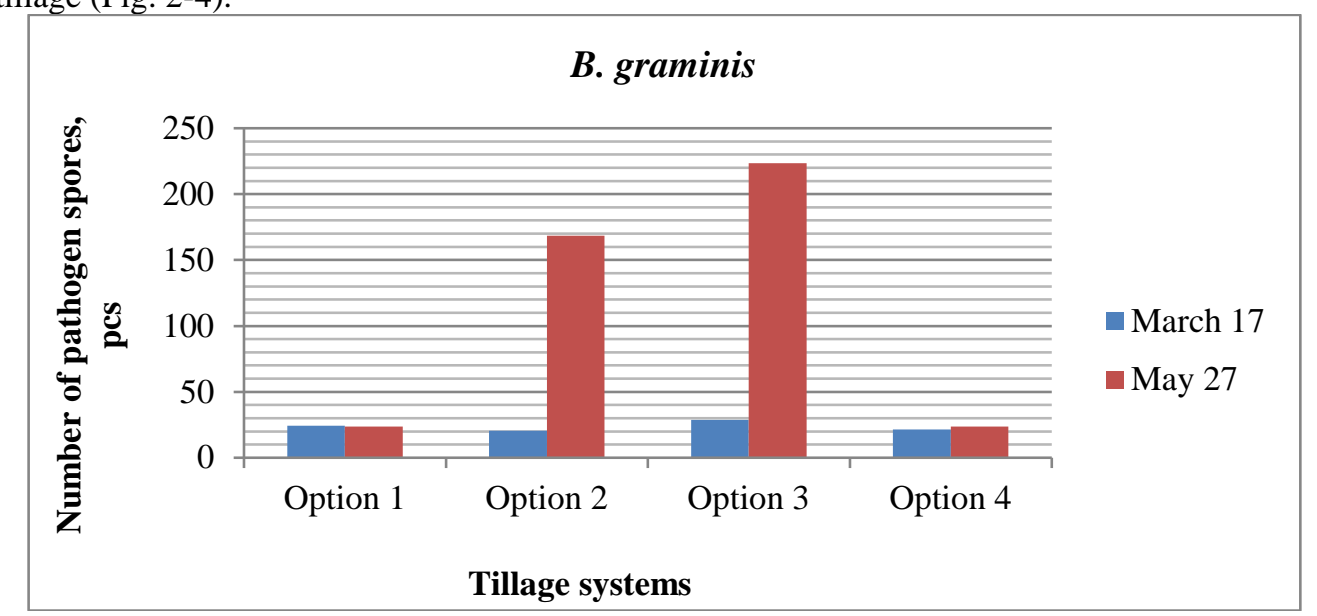

Fig. 2. The number of detected spores of the powdery mildew pathogen (B. graminis) in areas with different tillage systems.

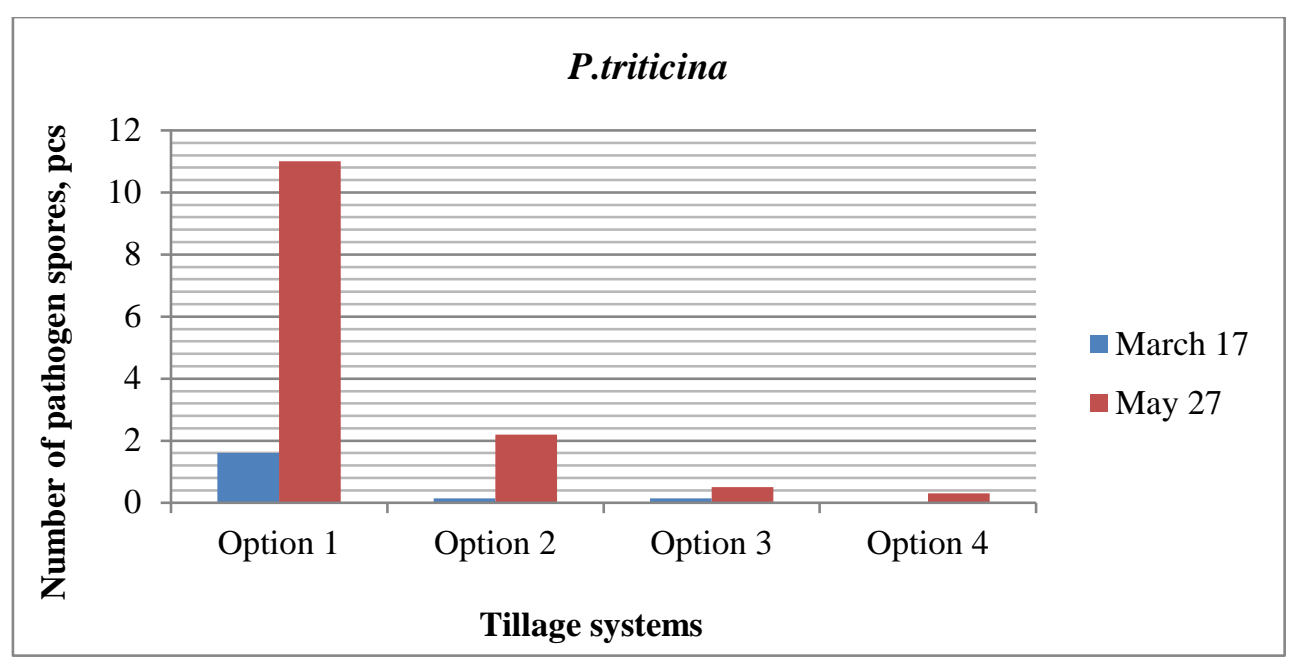

Fig. 3. The number of spores of the leaf rust pathogen (P. triticina) detected in areas with different tillage systems 


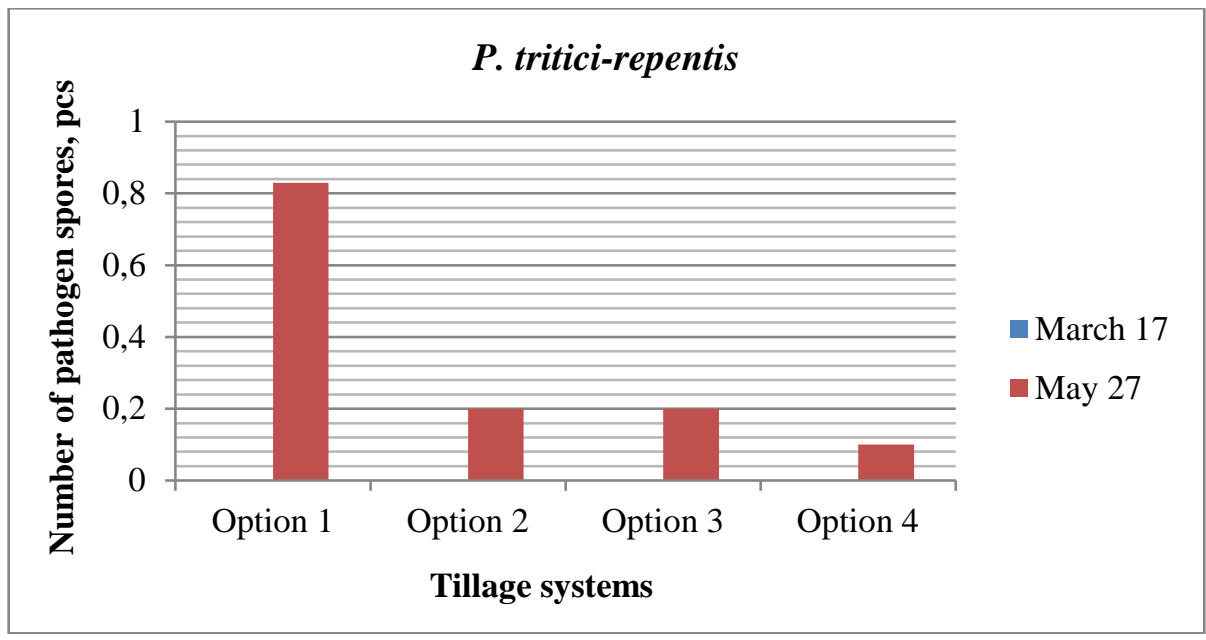

Fig. 4. The number of spores of pyrenophorosis pathogen (P. tritici-repentis) detected in areas with different tillage systems.

Thus, with zero technology, the soil is not processed mechanically, but is covered with mulch, on which phytopathogens survive the winter favorably, especially rust diseases and powdery mildew. With moldboardless tillage, loosening occurs, however, the lower layers of the soil are not brought to the surface, and weeds are cut without the accumulation of plant residues. As a result of loosening, the soil becomes more moist, which is favorable for the development of the septoria pathogen. With the recommended processing, surface (disking) and moldboard (plowing) technologies are combined. At the same time, the stubble is destroyed, as a result of which the places for the wintering of phytopathogens are reduced, therefore this type of treatment is effective against rust diseases. During moldboard tillage, the soil layers are completely or partially turned over, which leads to strong loosening and mixing of the soil, to cutting and embedding of the ground parts of the plants. The result is relatively less development of all diseases.

As a result, we traced the influence of the method of tillage on the development of leaf diseases in winter wheat and found that under these conditions it is most preferable to use the recommended type of tillage, since fewer diseases develop with it.

Also, we found a relationship between the degree of disease development and the number of phytopathogen spores. So, in the absence of signs of a disease with powdery mildew, the number of spores of this disease pathogen (B. graminis) ranges from 20 to 29 pieces. With the development of the disease $4.23 \%$, the number of spores is 168.4 pieces, and with $4.938 \%$ it is 223.4 pieces. Interestingly, during moldboard tillage with a degree of damage of $3.76 \%$, the number of spores remains practically unchanged compared to $0 \%$ development of the disease (at the level of 23.5 spores). Perhaps this is due to the fact that with this tillage type, soil moisture is less than with others, which limits the development of pathogens and the their production of spores.

The research was supported by the RFBR grant, the Administration of Krasnodar Krai No. 19-416230043 r_a and the framework of the State Assignment of the Ministry of Science and Higher Education of the Russian Federation on the topic No 0686-2019-0012. 


\section{References}

1. M. Koishybaev. Wheat diseases. Food and Agriculture Organization of the United Nations, Ankara. (2018) ISBN 978-92-5-130142-5.

2. S. A. Kurbanov. Agriculture. Moscow: Yurayt Publishing House. (2021) ISBN 978-5-53413817-7.

3. N.E. Rudenko. Mechanization of tillage. Stavropol: Publishing house of SSAU «AGRUS» (2005) ISBN 5-9596-0209-1.

4. E.Yu. Toropova, V.A. Chulkina, G.Ya. Stetsov. The influence of tillage methods on the phytosanitary state of crops. Plant protection and quarantine. №1, 26 -27. (2010).

5. A. Kokhmetova, O. Kremneva, G. Volkova, M. Atishova, Z. Sapakhova. Evaluation of wheat cultivars growing in Kazakhstan and Russia for resistance to tan spot. J. PlantPathology. 99(1), 161-167. (2017) https://doi.org/10.4454/jpp.v99i1.3812

6. O.Y. Kremneva, N. V. Mironenko, G.V. Volkova, O.A. Baranova, Y.S. Kim, N.M. Kovalenko. Resistance of winter wheat varieties to tan spot in the North Caucasus region of Russia. Saudi Journal of Biological Sciences. 28 (3), 17871794 (2021) https://doi.org/10.1016/j.sjbs.2020.12.021

7. G. V. Volkova, O. A. Kudinova, O. F. Vaganova. Postulation of leaf rust resistance genes of 20 wheat cultivars in southern Russia. Journal of Plant Protection Research, 60(3), 225232. (2020) https://doi.org/10.24425/jppr.2020.133951

8. FSBSI «P.P. Lukyanenko National Grain Center» https://ncz-russia.ru/sorta-pshenitsy/stepe/

9. A. P. Roelfs, R. P. Singh, E. E. Saari. Rust diseases of wheat: concepts and methods management (1992)

10. M. Koyshibaev, A.O. Sagitov. Protection of grain crops from especially dangerous diseases. (2012).

11. Yu.G. Sokolov, V.T. Sadkovsky, O. Yu. Kremneva, R.Yu. Danilov, A.A. Pachkin, R.A. Zelensky, A.A. Kurilov. International Research Journal. 12-2(78), 29-33 (2018) https://doi.org/10.23670/IRJ.2018.78.12.042 